\title{
Office of River Protection Monthly Performance Report - July 2000
}

K.J. Wagnild

U.S. Department of Energy, Office of River Protection

Date Published

October 2000

Prepared for the U.S. Department of Energy

Assistant Secretary for Environmental Management

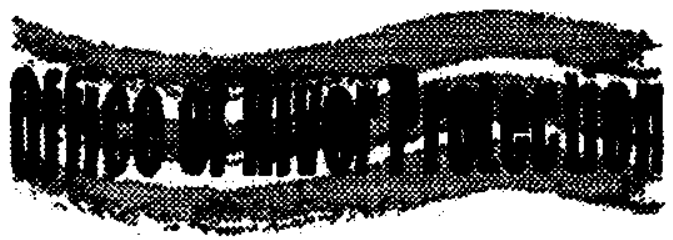

P.O. Box 450

Richland, Washington 99352

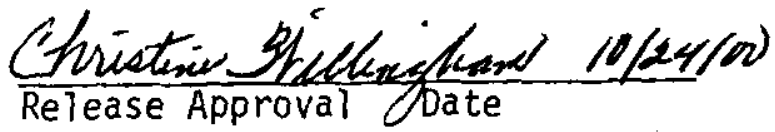




\section{INFORMATION CLEARANCE FORM}

A. Information Category

$\begin{array}{ll}\square \text { Abstract } & \square \text { Journal Article } \\ \square \text { Summary } & \square \text { Internet } \\ \square \text { Visual Aid } & \square \text { Software } \\ \square \text { Full Paper } & \square \text { Report } \\ \square \text { Other } & \end{array}$

B. Document Number DOE/ORP-99-05, REVISION 9

C. Title

Office of River Protection Monthly Performance Report - July 2000

D. Internet Address www. hanford.gov/orp/index. html
E. Required Information

1. Is document potentially Classified? $\square$ No $\square$ Yes (MANDATORY)

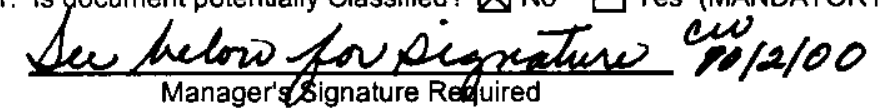
If Yes

ADC Signature Required

$\triangle$ No $\square$ Yes Classified

2. Internal Review Required? $\bigotimes$ No $\square$ Yes If Yes, Document Signatures Below

Counsel

Program

3. References in the Information are Applied Technology $\bigotimes$ No $\square$ Yes Export Controlled information $\nabla_{\text {No }} \square$ Yes
4. Does Information Contain the Following: (MANDATORY)

a. New or Novel (Patentable) Subject Matter? $\quad$ No $\square$ Yes

If "Yes", Disclosure No.:

b. Information Received in Confidence, Such as Proprietary and/or Inventions? $\bigotimes$ No $\square$ Yes If "Yes", Affix Appropriate Legends/Notices.

c. Copyrights? $\square$ No $\square$ Yes If "Yes", Attach Permission.

d. Trademarks? $\square$ No $\square$ Yes If "Yes", Identify in Document.

5. Is Information requiring submission to OSTI? $\square$ Yes If Yes UCand $B \& R-$

6. Release Level? $\square$ Public $\square$ Limited

7. Charge Code $110707 \quad H F R<0041$

\section{F. Complete for a Journal Article}

1. Title of Journal

\section{G. Complete for a Presentation}

1. Title for Conference or Meeting

2. Group Sponsoring

3. Date of Conference

5. Will Information be Published in Proceedings? $\square$ No $\square$ Yes H. Author/Requestor

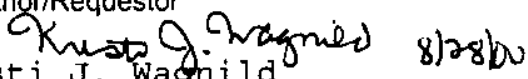
Kristi J.Wagnild (Print and Sign)

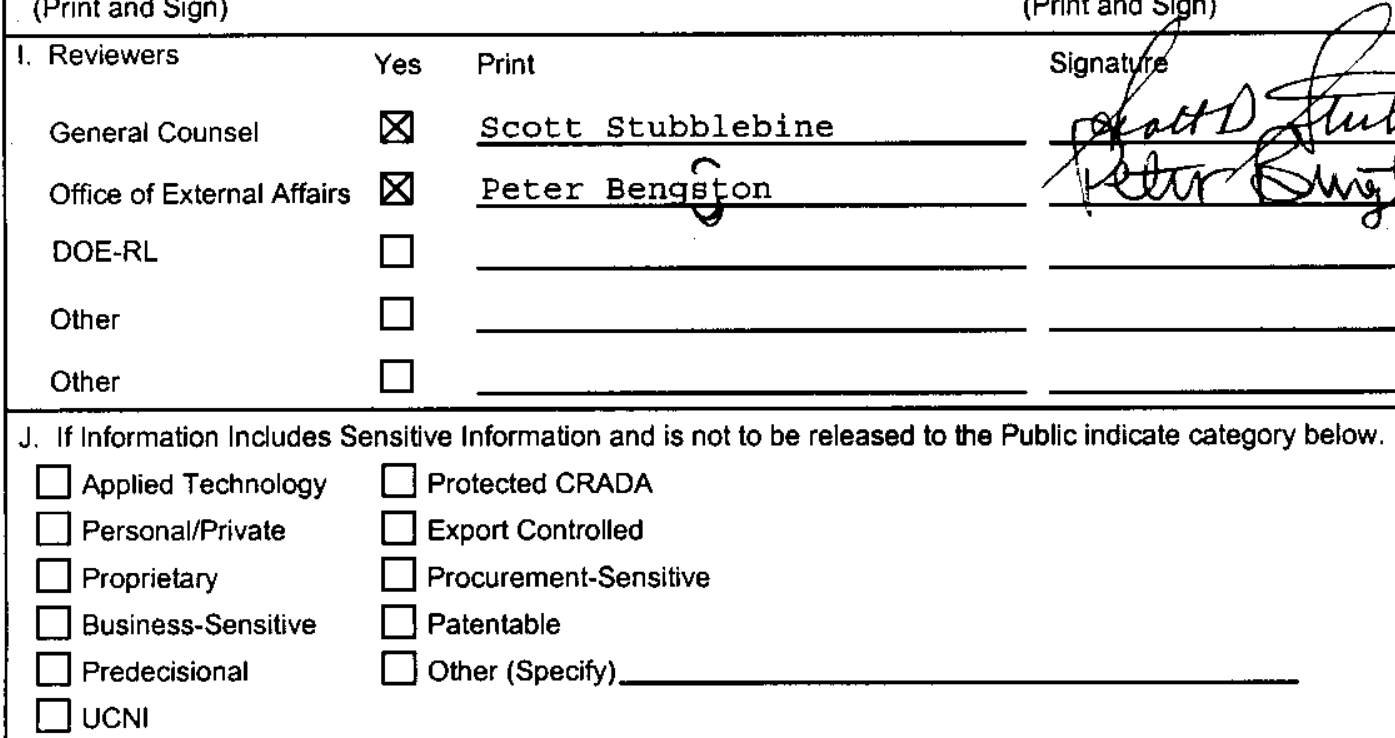

K. If Additional Comments, Please Attach Separate Sheet
4. City/State

6. Will Material be Handed Out? $\square$ No $\square$ Yes Kevin Ensign $\mathrm{K}$

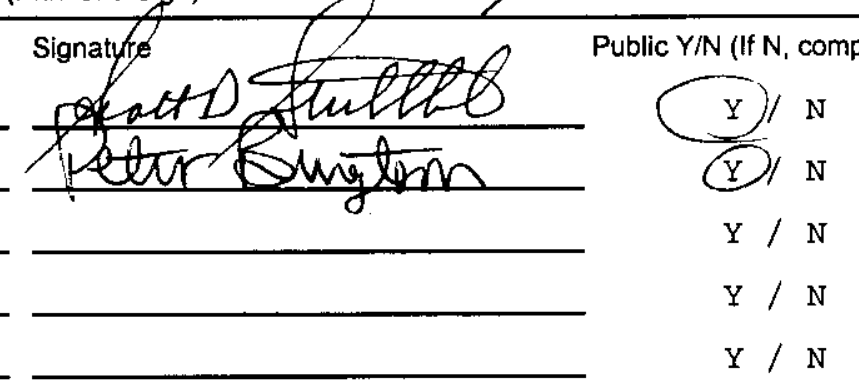




\section{Office of River Protection Monthly Performance Report - July 2000}
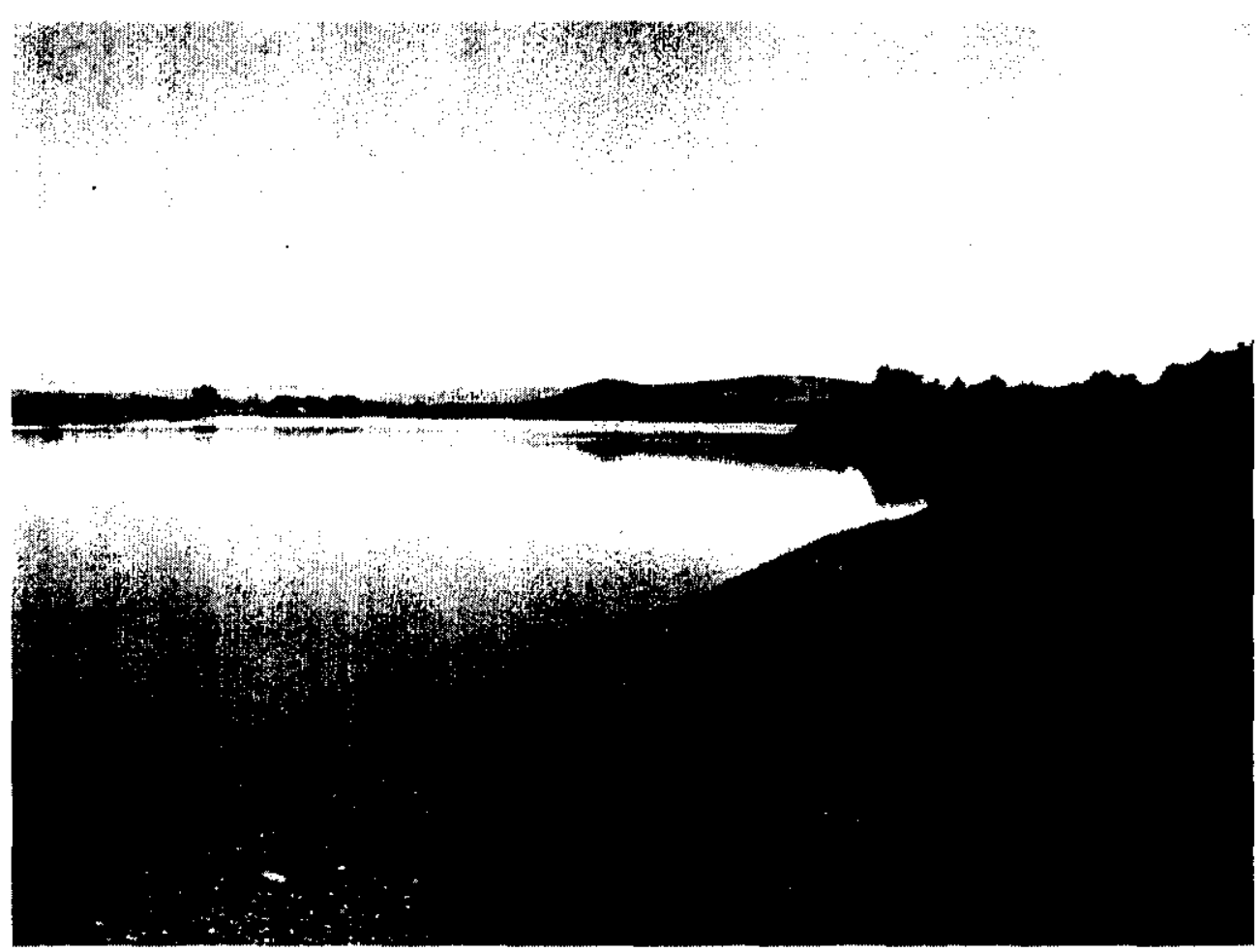

Prepared for the U.S. Department of Energy Assistant Secretary for Environmental Management

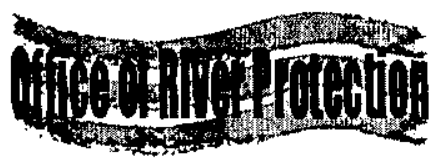

P.O. Box 450

Richland, Washington 99352 
DOE/ORP-99-05

Revision 9

\section{Office of River Protection Monthly Performance Report - July 2000}

Date Published

August 2000

Prepared for the U.S. Department of Energy

Assistant Secretary for Environmental Management

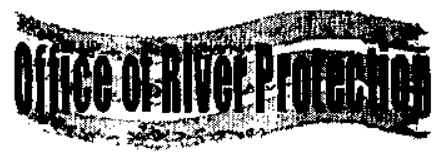

P.O. Box 450

Richland, Washington 99352 


\section{LEGAL DISCLAIMER}

This report was prepared as an account of work sponsored by an agency of the United States Government. Neither the United States Government nor any agency thereof, nor any of their employees, nor any of their contractors, subcontractors or their employees, makes any warranty, express or implied, or assumes any legal liability or responsibility for the

accuracy, completeness, or any third party's use or the results of such use of any information, apparatus, product, or process disclosed, or represents that its use would not infringe privately owned rights. Reference herein to any specific commercial product, process, or service by trade name, trademark, manufacturer, or otherwise, does not necessarily constitute or imply its endorsement, recommendation, or favoring by the United States Government or any agency thereof or its contractors or subcontractors. The views and opinions of authors expressed herein do not necessarily state or reflect those of the United States Government or any agency thereof.

This report has been reproduced from the best available copy. 


\section{RIVER PROTECTION PROJECT WBS 1.1}

\section{PROJECT MANAGERS:}

H. L. Boston, Acting Manager DOE-Office of River Protection Phone: (509) 376-6677

M. P. Delozier President and General Manager CH2M HILL Hanford Group, Inc. Phone: (509) 372-8061 


\section{Table of Contents}

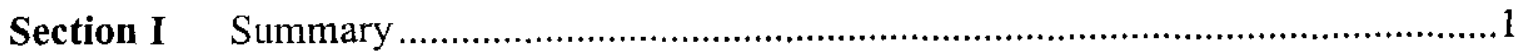

Upcoming Key Planned Events .........................................................

Section II Feed Delivery (CH2M HILL Hanford Group, Inc.)

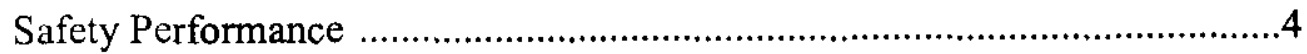

Milestone Performance ....................................................................4

Schedule Performance ...................................................................

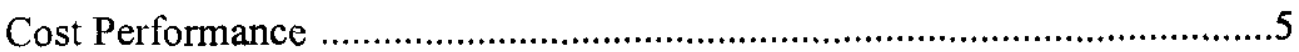

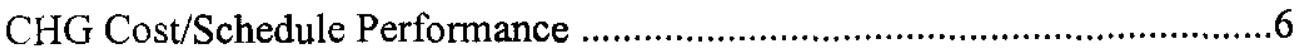

Feed Delivery Cost/Schedule Performance ............................................

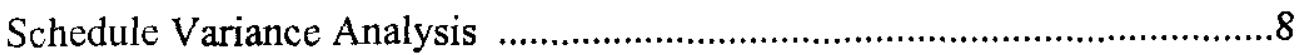

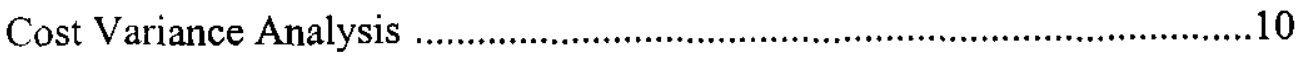

Milestone Achievement ..............................................................12

Section III Waste Treatment Plant (WTP)

WTP Cost/Schedule Performance ............................................................16 


\section{Section I}

\section{Summary}




\section{SUMMARY}

River Protection Project (RPP) performance for the month of July 2000 was very good. The most significant accomplishments that occurred during the month include the following:

The Interim Stabilization Project pumped approximately 30,000 gallons from four tanks. Project-to-date (since June 1998) volume pumped is approximately 808,000 gallons. Five tanks have been interim stabilized this fiscal year, and tanks 241-S-106, 241-U-103, and 241-U-105 are being evaluated to determine if the stabilization criteria have been met. Out of the 149 single-shell tanks (SSTs), 124 tanks have been stabilized. Pumping this waste from the single-shell tanks to more secure double-shell tanks (DSTs) supports stabilization of the waste tanks and mitigates leakage to the environment. The Interim Stabilization Project is planned to complete by September 2004.

Waste Characterization obtained one grab sample in the month of July 2000. A total of 14 core samples, 12 grab samples, and 6 vapor samples have been taken fiscal year-to-date (FYTD) in support of three key FY 2000 sampling milestones.

The Waste Treatment Plant Design and Operation organizations have been developed and staffed, including transitioning BNFL Inc./Bechtel National Inc. employees to CHG. Since the termination of the BNFL contract, CHG has temporarily assumed the work scope for design and operation of the Waste Treatment Plant. A new waste treatment facility will be built at the Hanford Site in which highly radioactive waste from the tanks will be turned into glass and permanently stored.

Approval of the Notice of Construction (NOC) for the AN Farm tank retrieval system was received from the U.S. Department of Energy (DOE) and the Environmental Protection Agency on July 21, 2000. This is a significant step forward for Project W-211, "Initial Tank Retrieval Systems" in preparing waste for delivery to the Waste Treatment Plant.

The preliminary report for the 241-AZ-101 mixer pump test was issued on July 18, 2000. The report provides results from the test that was performed in April through June 2000. The test demonstrated satisfactory performance of the pump throughout the range of operations and showed that sludge can be sufficiently mobilized to provide feed to the Waste Treatment Plant.

A responsibility, availability, and maintainability (RAM) analysis report for tank retrieval systems was issued on July 18,2000 , which identified RAM recommendations for waste feed delivery systems. The report translates the DST system RAM requirements into practical design requirements for specific DST waste feed delivery components. This is an important step in beginning the design stages for the waste feed delivery system, which will transfer waste that has been retrieved from the tanks to the Waste Treatment Plant.

The Immobilized High Level Waste/Immobilized Low Activity Waste (IHLW/ILAW) sample transport strategy document was issued, indicating a cost savings of $\$ 100 \mathrm{~K}$ this fiscal year, and life cycle savings of $\$ 20$ million. The significant cost savings will result from using existing transport equipment, services, and facilities, as opposed to using new buildings and equipment for transporting waste for disposal. 


\section{UPCOMING KEY PLANNED EVENTS IN THE NEXT 90 DAYS}

- Issue Request for Proposal for design, construction, and commission of the Waste Treatment and Immobilization Plant (WTP) to treat and immobilize Hanford tank waste (August).

- CHG submit to ORP the Final Waste Information Requirements Document for FY 2001, M-44-14D (Waste Characterization) (August).

- Start interim stabilization of three SSTs: 241-A-101, 241-AX-101, and 241-SX-105 (August).

- Reduce total organic complexant pumpable liquids from approximately 45 percent to 38 percent of total volume from SSTs (August).

- Grab sample tank 241-AW-104, core sample tanks 241-AN-104 and 241-AZ-101, and vapor sample the SY Exhauster (August).

- Re-evaluate the post tank 241-C-106 sluicing hazards in tank 241-AY-102 and tank 241-C-106 (August).

- Complete effluent transfer system design modifications (August).

- Complete the RPP Business Execution Plan (August).

- Grab sample tanks 241-S-101 and 241-S-107, and vapor sample tank 241-SY-102 (September).

- CHG submit a recommendation to ORP to adjust the authorization basis to remove the mixer pump requirement from tank 241-SY-101 (September).

- Complete the design of the transfer system tie-ins and associated specifications to connect tank 241-SY-101 to the cross-site transfer system (September).

- Complete Tri-Party Agreement Milestone M-46-00G, Double-Shell Tank Space Evaluation (September).

- Complete Tri-Party Agreement Milestone M-45-02E, annual update of SST retrieval sequence document (September).

- Drill five RCRA wells (vadose zone) (September).

- Retrieve waste from tank 241-C-104 (September).

- Complete installation of substation telecommunications (September).

- Submit strategies/plans for disposal of HLW/LAW melters (September).

- Issue final revised IHLW and ILAW program plans (September).

- Complete FY01 Baseline and Bridge BCR (September).

- Resume operations and design critical path activities leading to the initiation of construction of the Waste Treatment Plant (ongoing). 


\section{Section II}

\section{Feed Delivery}

\section{CH2M HILL Hanford Group, Inc. (CHG)}

PROJECT MANAGER:

M. P. Delozier President and General Manager CH2M HILL Hanford Group, Inc. Phone: (509) 372-8061 


\section{Feed Delivery - CH2M HILL Hanford Group, Inc. (CHG)}

\section{SAFETY PERFORMANCE}

There were fourteen first aid cases, two OSHA recordable cases, and zero lost workdays. The majority of the cases resulted from minor cuts, strains/sprains, and insect bites to workers in the field. Although the first aid case rate increased by two from June to July, the overall company safety performance remains very good. The 12-month rolling average recordable rate decreased from 3.27 to 2.90 . Safety behavior has improved as a result of increased management and worker attention; and focused safety corrective action meetings. The all day safety event, "Communicate the Commitment day," held on June 16,2000 , proved to heighten safety awareness and enforce the importance of safety as the number one priority for all $\mathrm{CHG}$ employees.

\section{MILESTONE PERFORMANCE}

CHG has 70 reportable milestones scheduled for FY 2000, consisting of 15 Enforceable Agreement milestones and 55 ORP-level milestones. Twenty milestones have been completed early, seven milestones have been completed on schedule, one milestone was completed one day late, three milestones have been missed, two milestones are forecast late (which are in the process of being cancelled), and thirty-seven milestones are forecast on schedule. The three ORP-level overdue milestones ("FY 2000 Quarter 3 - maintain average pump efficiency of 50\%," due June 30, 2000; "Contractor deliverable to M-43-14, start construction for upgrades in the third tank farm," due June 20 , 2000; and "Review BNFL deliverables and perform a gap analysis," due June 15, 2000), have been missed due to saltwell pumping equipment problems, AY tank farm construction delays, and DOE-ORP cancellation of the BNFL contract. Efforts to maintain saltwell pumping efficiency continue; construction schedule recovery for tank farm upgrades is underway; and the BNFL gap analysis is being deleted (per DOE-ORP direction) via change control. Two ORP-level milestones ("Complete Work Management Pilot," due August 7, 2000; and "RPP Information Systems Development," due September 15,2000 ) will be deleted due to refocusing on commercial off-the-shelf software for the business system solution. BCR RPP-00-115 is in process to delete the milestones.

\section{SCHEDULE PERFORMANCE (\$M)}

\begin{tabular}{|l|c|c|c|}
\hline & BCWP & BCWS & VARIANCE \\
\hline RPP TOTAL & $\$ 278.1$ & $\$ 289.5$ & $(\$ 11.4)$ \\
\hline
\end{tabular}

\section{SCHEDULE VARIANCE}

The majority of the $\$ 11.4$ million (-4.0 percent) unfavorable schedule variance is within Waste Characterization, Tank Farm Operations, Waste Retrieval, and Management Support. The unfavorable schedule variance in Waste Characterization is due to sample analysis being behind schedule at the 222$\mathrm{S}$ laboratory, as a result of the large backlog of samples. 


\section{SCHEDULE VARIANCE (continued)}

The schedule variance in Tank Farm Operations results from material delays for field hardware upgrades of tank monitoring and air control systems, and continuous air monitors. Environmental, Safety, Health, and Quality (ESH\&Q) activities are behind schedule due to diversion of resources to support higher priority emergent work scope earlier in the fiscal year (tank 241-SY-101 pumping, cross-site waste transfers, and 244-AR vault activities). Project W-314, "Tank Farm Restoration and Safe Operations," continues to report an unfavorable construction schedule variance due to $\mathrm{SN}$ transfer line and piping issues. Receiving materials for the field upgrade activities will allow for schedule recovery. Resources are being restored to the ESH\&Q activities. Work on Project W-314 aggressively continues.

Excavation of the re-routed SN-635 line is complete, and an alternate SN-635 pipe was delivered in July 2000. The construction schedule is being recovered through productivity initiatives and increased resources.

The Waste Retrieval unfavorable schedule variance is due to placing the Operations and Maintenance (O\&M) concept on hold pending the funding gap resolution. In addition, DST Retrieval System Development activities are contributing to the negative schedule variance, due to time-phasing issues in the schedule. Work will be completed by fiscal year-end. BCR RPP-00-131 is in process to defer the O\&M concept to FY01. The unfavorable schedule variance within Management Support results from upgrades to the work management system being stopped in order to re-focus on commercial off-theshelf, less expensive and user friendly software for the business system solution. BCR RPP-00-115 is in process to delete work management activities from the baseline. It is anticipated that all remaining work scope will be completed by fiscal year-end.

\section{COST PERFORMANCE (\$M)}

\begin{tabular}{|l|c|c|c|}
\hline & BCWP & ACWP & VARIANCE \\
\hline RPP TOTAL & $\$ 278.1$ & $\$ 267.3$ & $\$ 10.8$ \\
\hline
\end{tabular}

\section{COST VARIANCE}

The favorable cost variance of $\$ 10.8$ million $(+3.9$ percent) results from positive cost variances of approximately $\$ 12.2 \mathrm{M}$, including a credit passback of $\$ 6.0 \mathrm{M}$ for approved reductions in the Fluor Hanford and CHG overhead pools; and efficiencies of approximately $\$ 6.2 \mathrm{M}$ realized in core sampling; program management activities; flammable gas activities; Project W-211, "Initial Tank Retrieval Systems" design activities, Project W-519, "Vitrification Plant Infrastructure" construction; and ILAW/IHLW engineering studies. Efficiencies are being used to fund emerging work scope, and to accelerate baseline work scope.

The favorable cost variance is slightly offset by a negative cost variance of $\$ 1.4 \mathrm{M}$ in Management Support, due to unplanned costs for project delivery activities, and costs for the BNFL transition. Costs for these activities will be managed through funds control. 


\section{FY2000 Cost/Schedule Performance - All Fund Types \\ CH2M HILL Hanford Group, Inc. Only \\ Cumulative Status to Date (Dollars in Millions)}

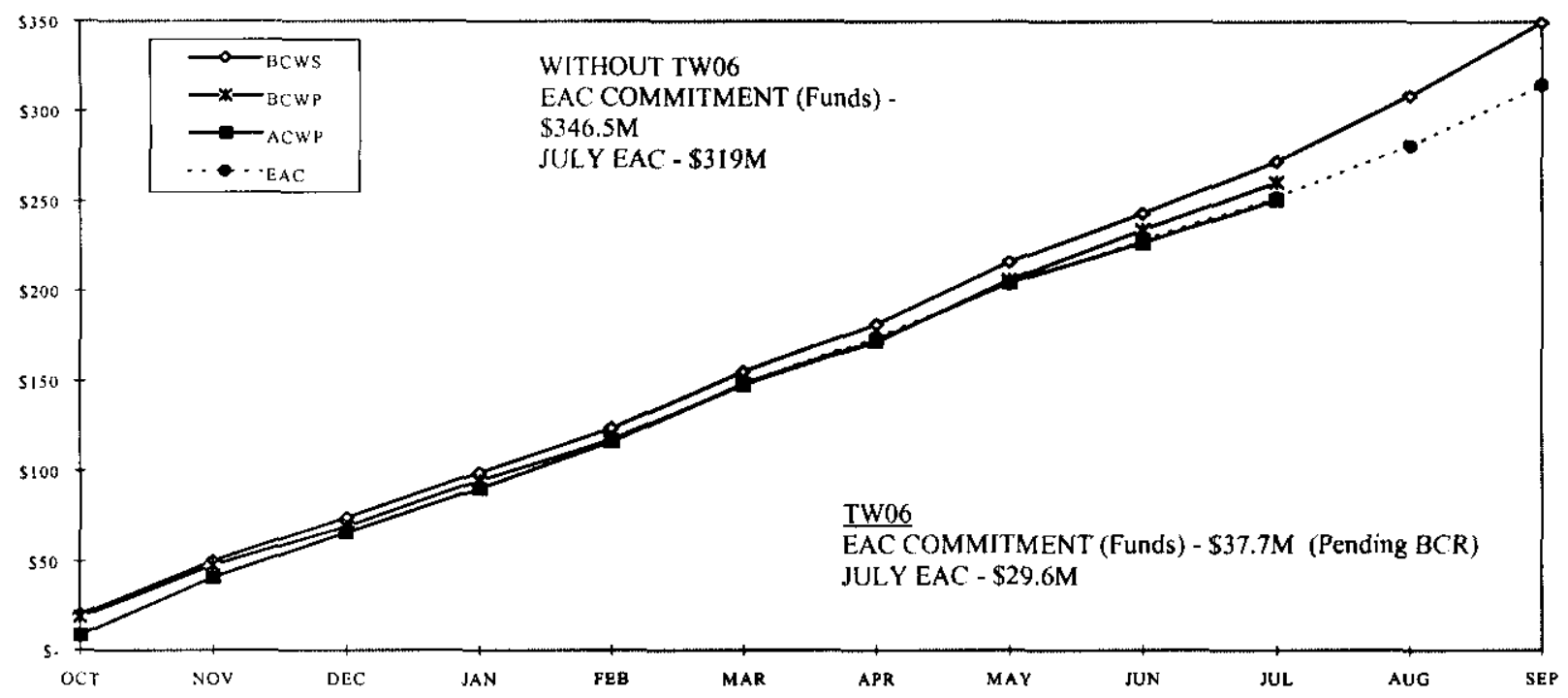

\begin{tabular}{|c|c|c|c|c|c|c|c|c|c|c|c|c|}
\hline & OCT & NOV & DEC & JAN & FEB & MAR & APR & MAY & JUN & SUL & AUG & SEP \\
\hline BCWS & 20.2 & 50.1 & 740 & 98.8 & 123,5 & 154.8 & 181.3 & 216.1 & 243.2 & 272.0 & 308.8 & 349.5 \\
\hline ECWP & 18.7 & 47.7 & 69.0 & 84.4 & 117,1 & 147.7 & 171.7 & 206.2 & 234.1 & 260.6 & & \\
\hline ACWP & 8.5 & 40.9 & 65.7 & 89.9 & 116.1 & 148.1 & 172.3 & 204.6 & 226.8 & 250.8 & & \\
\hline$s v$ & $(1.5)$ & (2.4) & $(5.0)$ & (4.4) & (6.4) & (7.1) & $(9,6)$ & $(9.8)$ & (9.11 & $(11,4)$ & & \\
\hline $\mathrm{cv}$ & 10.2 & 6.8 & 3.3 & 4.5 & 1.0 & $(0,4)$ & $(0.6)$ & 1.6 & 73 & 8.7 & & \\
\hline sv\% & $(7.4 \%)$ & $(4.9 \%)$ & $(6.8 \%)$ & $(4.5 \%)$ & $\left(5.2 \psi_{0}\right)$ & $(4.6 \%)$ & $(5.3 \%)$ & $14.6 \%$ & $(3,7 \%)$ & $(4.2 \%)$ & & \\
\hline CV\% & $54.7 \%$ & $14.0 \%$ & $4.7 \%$ & $4.7 \%$ & $.8 \%$ & $(2 \%)$ & $(4 \%)$ & $8 \%$ & $3.1 \%$ & $3.7 \%$ & & \\
\hline
\end{tabular}

FY 2000 Cost/Schedule Performance - All Fund Types

CH2M HILL Hanford Group, Inc. Only

Cumulative Status to Date (Dollars in Millions)

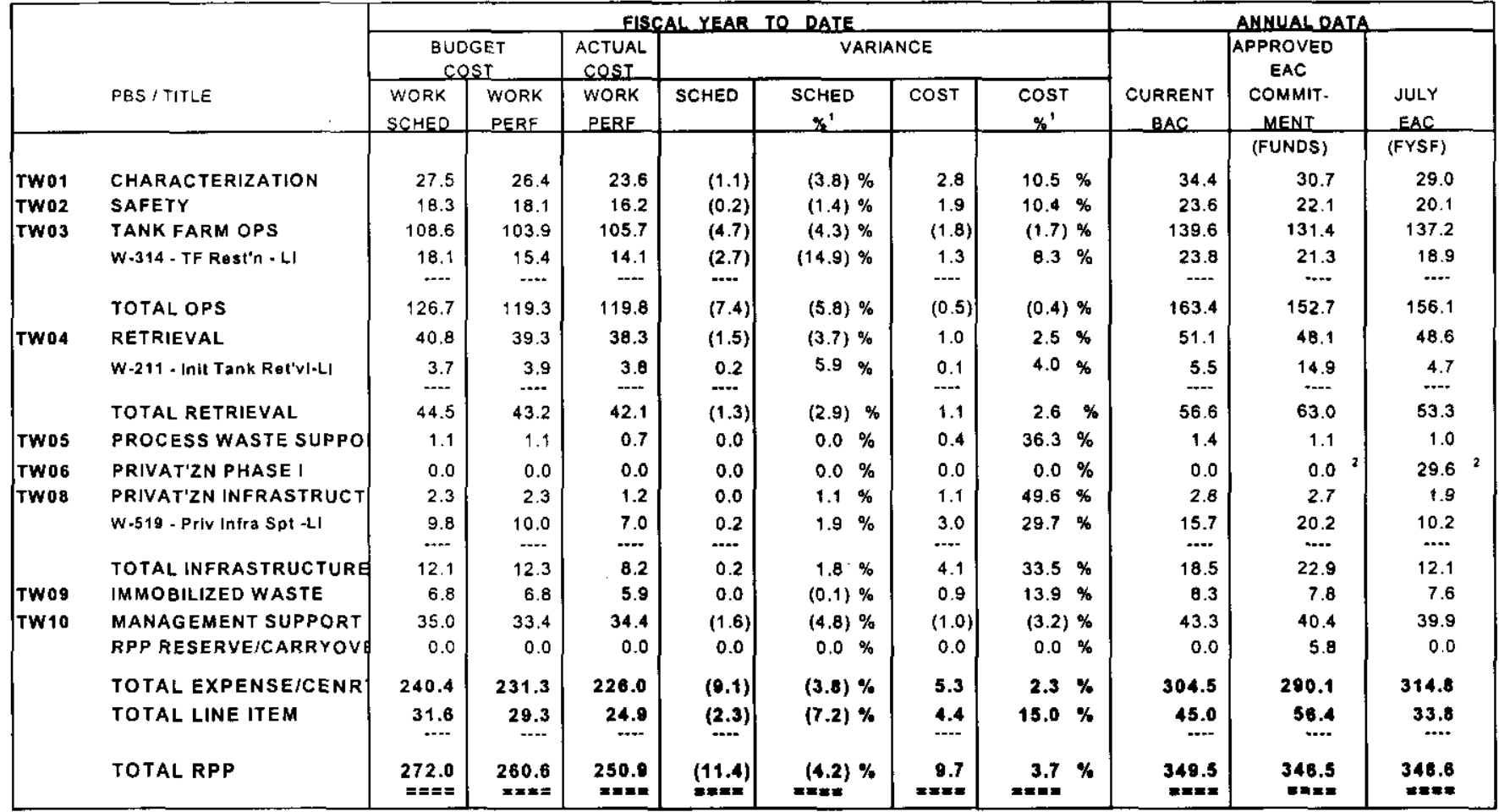

${ }^{1}$ Schedule and Cost variance values \& percentages calculated based on $\mathbf{\$}$ In thousands.

Shading represents variances outside the threshold of $-7.5 \%$ schedule varlance and $\mathbf{5 \%}$ cost varlance.

${ }^{2}$ Approved funding equals $\$ 0$; current contract funding is $\$ 7.0 \mathrm{M}$. Pending BCR of $\$ 37.7 \mathrm{M}$ is currently awaiting approval. 


\section{FY 2000 Total Cost/Schedule Performance - All Fund Types (Including All Direct Funded Activities) \\ Cumulative to Date Status (Dollars in Millions)}

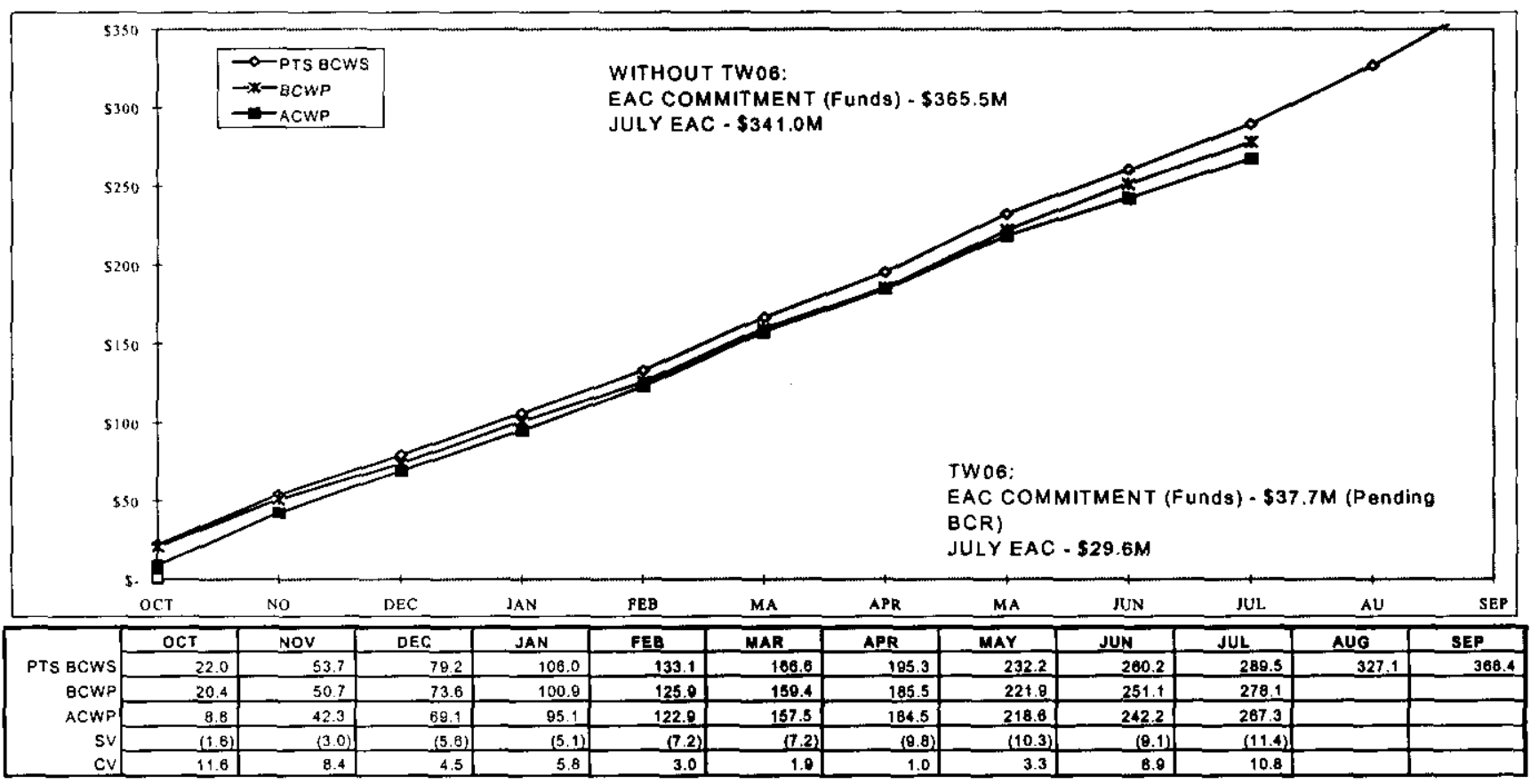

FY 2000 Total Cost/Schedule Performance - All Fund Types (Including All Direct Funded Activities)

Cumulative Status to Date (Dollars in Millions)

\begin{tabular}{|c|c|c|c|c|c|c|c|c|c|c|c|}
\hline & \multirow{3}{*}{ PES / TITLE } & \multicolumn{7}{|c|}{ FISCAL YEAR TO DATE } & \multicolumn{3}{|c|}{ ANNUAL DATA } \\
\hline & & \multicolumn{2}{|c|}{$\begin{array}{c}\text { BUDGET } \\
\text { COST }\end{array}$} & \multirow{2}{*}{$\begin{array}{c}\text { ACTUAL } \\
\text { COST } \\
\text { WORK } \\
\text { PERE } \\
\end{array}$} & \multicolumn{4}{|c|}{ VARIANCE } & \multirow[b]{2}{*}{$\begin{array}{c}\text { CURRENT } \\
\text { BAC }\end{array}$} & \multirow{2}{*}{$\begin{array}{c}\text { APPROVED } \\
\text { EAC } \\
\text { COMMIT- } \\
\text { MENT } \\
\end{array}$} & \multirow[b]{2}{*}{$\begin{array}{l}\text { JULY } \\
\text { EAC }\end{array}$} \\
\hline & & $\begin{array}{l}\text { WORK } \\
\text { SCHED }\end{array}$ & $\begin{array}{l}\text { WORK } \\
\text { PERF } \\
\end{array}$ & & SCHED & $\begin{array}{c}\text { SCHED } \\
\%^{1} \\
\end{array}$ & $\cos T$ & $\begin{array}{r}\text { Cost } \\
\%^{1} \\
\end{array}$ & & & \\
\hline & & & & & & & & & & (FUNDS) & (FYSF) \\
\hline \multicolumn{12}{|c|}{ ALLFUND TYPES } \\
\hline IWO1 & CHARACTERIZATION & 27.6 & 26.6 & 23.7 & $(1.0)$ & $(3.8) \%$ & 2.9 & $10.9 \%$ & 34.7 & 30.9 & 29.2 \\
\hline INO2 & SAFETY & 19.8 & 19.5 & 17.0 & $(0.2)$ & (1.3) \% & 2.5 & $12.9 \%$ & 25.2 & 23.7 & 21.5 \\
\hline \multirow[t]{4}{*}{ INO3 } & TANK FARM OPS & 111.1 & 106.4 & 106.6 & $(4.7)$ & $(4.2) \%$ & $(0.2)$ & $(0.2) \%$ & 142.7 & 134.6 & 139.8 \\
\hline & W-314 - TF Rest'n - LI & 18.1 & 15.4 & 14.1 & $(2.7)$ & $(14.9) \%$ & 1.3 & $8.3 \%$ & 23.8 & 21.3 & 18.9 \\
\hline & & $\cdots$ & $\cdots$ & $\cdots$ & $\rightarrow$ & & $\cdots$ & & $\cdots$ & $\cdots$ & --- \\
\hline & TOTAL OPS & 129.2 & 121.8 & 120.7 & (7.4) & $(5.7) \%$ & 1.1 & $0.9 \%$ & 166.5 & 155.9 & 158.7 \\
\hline \multirow[t]{4}{*}{ INAO4 } & RETRIEVAL & 41.7 & 40.2 & 39.1 & $(1.5)$ & $(3.7) \%$ & 1.1 & $2.9 \%$ & 52.3 & 49.4 & 49.7 \\
\hline & W-211 - Init Tank Ret'vI-LI & 3.7 & 3.9 & 3.8 & 0.2 & $5.8 \%$ & 0.1 & $4.0 \%$ & 5.5 & 14.9 & 4.7 \\
\hline & & $\cdots$ & $-\cdots$ & $\cdots$ & - & & $\cdots$ & & 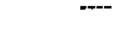 & 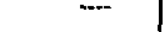 & $\cdots$ \\
\hline & TOTAL RETRIEVAL & 45.5 & 44.1 & 42.9 & $(1.3)$ & $(2.9) \%$ & 1.2 & $3.0 \%$ & 57.8 & 64.3 & 54.4 \\
\hline Twos & PROCESS WASTE SUPPORT & 8.3 & 8.3 & 9.2 & 0.0 & $0.0 \%$ & $(0.9)$ & $(10.8) \%$ & 8.5 & 8.3 & 11.8 \\
\hline IWNa6 & PRIVAT'ZN PHASE I & 0.0 & 0.0 & 0.0 & 0.0 & $0.0 \% \%$ & 0.0 & $0.0 \%$ & 0.0 & $0.0^{2}$ & 29.6 \\
\hline \multirow[t]{4}{*}{ INOB } & PRIVAT'ZN INFRASTRUCTUR & 2.5 & 2.5 & 1.3 & 0.1 & $1.0 \%$ & 1.2 & $49.0 \%$ & 3.1 & 3.0 & 2.1 \\
\hline & W.519-Prix Infra Spt - LI & 9.8 & 10.0 & 7.0 & 0.2 & $1.9 \%$ & 3.0 & $29.7 \%$ & 15.7 & 20.2 & 10.2 \\
\hline & & $\cdots$ & $\cdots$ & $\cdots$ & $\cdots$ & & -- & & $\cdots$ & -- & $\cdots$ \\
\hline & TOTAL INFRASTRUCTURE & 12.3 & 12.5 & 8.3 & 0.3 & $1.7 \%$ & 4.2 & $33.6 \%$ & 18.8 & 23.2 & 12.3 \\
\hline Iwos & IMMOAILIZED WASTE & 7.2 & 7.2 & 8.1 & $\langle 0.0\rangle$ & $0.1 \%$ & 1.1 & $14.5 \%$ & 8.8 & 8.2 & 8.0 \\
\hline \multirow[t]{6}{*}{ IW10 } & MANAGEMENT SUPPORT & 39.7 & 38.1 & 39.4 & $(1.7)$ & $(4.2) \%$ & (1.3) & (3.6) \% & 48.1 & 45.2 & 45.0 \\
\hline & RPP RESERVE/CARRYOVER & & & & & & & & & 5.8 & - \\
\hline & TOTAL RPP EXP/CE & 257.9 & 248.8 & 242.4 & $(0.1)$ & (3.6) $\%$ & 6.4 & $2.6 \%$ & 323.4 & 309.1 & 336.8 \\
\hline & TOTAL RPP LI & 31.6 & 29.3 & 24.0 & (2.3) & $\{7.2\} \%$ & 4.4 & $15.0 \%$ & 45.0 & 56.4 & 33.8 \\
\hline & 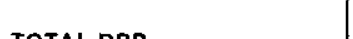 & $\cdots$ & -... & --. & $-\infty$ & & $-i$ & & --- & $\cdots$ & 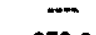 \\
\hline & TOTAL RPP & 289.5 & 278.1 & 267.3 & $(14.4)$ & $(4.0) \%$ & 10.8 & $3.9 \%$ & 388.4 & 365.5 & 370.6 \\
\hline
\end{tabular}

Schedule and Cost variance percentages are calculated based on $\$$ in thousands.

${ }^{2}$ Approved funding equals $\$ 0$; current contract funding is $\$ 7.0 \mathrm{M}$. Pengling BCR of $\$ 37.7 \mathrm{M}$ is currently awalting approval. 


\section{SCHEDULE VARIANCE ANALYSIS (\$11.4M)}

\section{$\underline{\text { WBS/PBS }} \quad \underline{\text { Title }}$}

1.01.01/TW01 Tank Waste Characterization

Description and Cause: The unfavorable schedule variance $(-\$ 1.0 \mathrm{M} ;-3.8 \%)$ is due to sample analysis at the 222-S lab being behind schedule as a result of the large backlog of samples.

Impact: No milestones are impacted.

Corrective Action: The lab continues to work the backlog of sample analyses. Schedule recovery will be achieved through the use of authorized overtime.

\subsubsection{2/TW02 Tank Safety Issue Resolution}

Description and Cause: The unfavorable schedule variance $(-\$ 0.2 \mathrm{M} ;-1.3 \%)$ is within the reporting threshold of negative 7.5 percent; therefore, no explanation is required at this time.

Impacts: None required.

Corrective Action: None required.

\subsubsection{3/TW03 Tank Farm Operations}

Description and Cause: The unfavorable schedule variance $(-\$ 7.4 \mathrm{M} ;-5.7 \%)$ is due to field hardware upgrades of tank monitoring and air control systems, and continuous air monitors being behind schedule due to delays in receiving materials. Environmental, Safety, Health, and Quality (ESH\&Q) activities (internal and external assessments) are behind schedule due to diversion of resources to support higher priority emergent work scope earlier in the fiscal year (tank 241-SY-101 pumping, cross-site waste transfers, and 244-AR vault activities). RCRA Part B Permit activities are behind schedule due to delays in receiving comments from Ecology. Project W-314, "Tank Farm Restoration and Safe Operations," continues to report an unfavorable construction schedule variance due to SN transfer line and piping issues.

Impacts: Milestone T03-00-057, contractor deliverable for M-43-14, to start construction of upgrades in the third tank farm, due June 30,2000 has been missed.

Corrective Action: Receiving materials for the field upgrade activities will allow for schedule recovery. Resources arc being restored to the ESH\&Q activities, and the schedule for RCRA Part B Permit activities will be recovered once comments are received from Ecology. For Project W-314, excavation of the re-routed SN-635 line is complete, and an alternate $\mathrm{SN}-635$ pipe was delivered in July. The construction schedule is being recovered through productivity initiatives and increased resources.

\subsubsection{4/TW04 Retrieval Project}

Description and Cause: The unfavorable schedule variance $(-\$ 1.3 \mathrm{M} ;-2.9 \%)$ is primarily due to DST Retrieval System Development activities (trade studies and tank farm evaluations) being behind schedule due to time-phasing issues in the schedule; and the operations and maintenance (O\&M) concept has been placed on hold pending the gap resolution.

Impact: There are no impacts at this time.

Corrective Action: Work will be completed by year-end. BCR RPP-00-131 is in process to defer the O\&M concept to FY01. 


\section{SCHEDULE VARIANCE ANALYSIS (\$11.4M) (continued)}

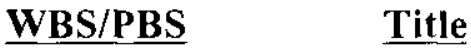

\subsubsection{5/TW05 Process Waste Support}

Description and Cause: There is no schedule variance; therefore, no explanation is required at this time.

Impact: None required.

Corrective Action: None required.

\subsubsection{8/TW08 Privatization Infrastructure}

Description and Cause: The favorable schedule variance $(\$ 0.3 \mathrm{M} ; 1.7 \%)$ is due to completing road work for access to the vitrification facility approximately two weeks ahead of schedule.

Impact: No impacts.

Corrective Action: None required.

\subsubsection{9/TW09 Immobilized Waste}

Description and Cause: There is no schedule variance; therefore, no explanation is required at this time. Impact: None required.

Corrective Action: None required.

\subsubsection{0/TW10 Management Support}

Description and Cause: The unfavorable schedule variance $(-\$ 1.7 \mathrm{M} ;-4.2 \%)$ is primarily due to Work Management activities being stopped in order to re-focus on a commercial off-the-shelf, less expensive and user-friendly software program for the business system solution.

Impacts: Milestone T10-00-200, Complete Work Management Pilot at RPP, will be deleted. Corrective Action: BCR RPP-00-115 is in process to delete Work Management activities from the baseline. Approval of the BCR is anticipated in August 2000. 


\section{COST VARIANCE ANALYSIS \$10.8M}

\subsubsection{1/TW01 Tank Waste Characterization}

Description and Cause: The favorable cost variance $(\$ 2.9 \mathrm{M} ; 10.9 \%)$ is due to a credit passback for approved reductions in the Fluor Hanford and CHG overhead pools; and efficiencies in core sampling operations driven by the elimination of several planning packages for equipment set-up and tear-down, thus reducing planning and craft labor costs. Additional cost savings are reflected in Program Management and data development activities as a result of labor underruns. The positive cost variance is partially offset by higher than anticipated costs from the 222-S laboratory, resulting from overtime and expedited service on lab assessments.

Impact: There are no impacts.

Corrective Action: Efficiencies are being used to perform emerging and accelerated work scope.

\subsubsection{2/TW02 Tank Safety Issue Resolution}

Description and Cause: The favorable cost variance $(\$ 2.5 \mathrm{M} ; 12.9 \%)$ is due to a credit passback for approved reductions in the Fluor Hanford and CHG overhead pools; and efficiencies in Flammable Gas activities.

Impact: There are no impacts.

Corrective Action: Efficiencies have been identified for re-allocation to other high priority CHG needs.

\subsubsection{3/TW03 Tank Farm Operations}

Description and Cause: The favorable cost variance $(\$ 1.1 \mathrm{M} ; 0.9 \%)$ is due to a credit passback for approved reductions in the Fluor Hanford and CHG overhead pools; and Project W-314 efficiencies in Phase II planning, Project Management, and design.

Impact: There are no impacts.

Corrective Actions: None required.

\subsubsection{4/TW04 Retrieval Project}

Description and Cause: The favorable cost variance $(\$ 1.2 \mathrm{M} ; 3.0 \%)$ is primarily due to a credit passback for approved reductions in the Fluor Hanford and CHG overhead pools; efficiencies in vadose zone characterization activities; Project W-521, "Waste Feed Delivery Systems" conceptual design, due to subcontract awards being done in phases; and Project W-211, "Initial Tank Retrieval Systems" efficiencies on Title II designs for the AZ-102, AN-104, AP-102/104 retrieval systems from lessons learned on previous designs. In addition, a contract for Project W-523, SST High Level Waste Retrieval System, Phase 1 project definition support was awarded for less than what was estimated. The favorable cost variance is partially offset by additional costs for overtime and contract work (equipment installation and unplanned corrective maintenance) to support the accelerated 24l-AZ-101 mixer pump test effort. Impact: There are no significant impacts at this time.

Corrective Action: BCR RPP-00-108 is in process to address the additional costs for the 241-AZ-101 mixer pump test.

\subsubsection{5/TW05 Process Waste Support}

Description and Cause: The unfavorable cost variance $(-\$ 0.9 \mathrm{M} ;-10.8 \%)$ is a result of the budget for this PBS not being aligned with the MYWP.

Impact: There are no impacts at this time.

Corrective Action: Change request RPP-00-130 is in process to increase the budget to align the work plan with the MYWP. 


\section{COST VARIANCE ANALYSIS \$10.8M (continued)}

$\underline{\text { WBS} / \text { PBS }} \quad \underline{\text { Title }}$

\subsubsection{8/TW08 Privatization Infrastructure}

Description and Cause: The favorable cost variance $(\$ 4.2 \mathrm{M} ; 33.6 \%)$ is due to Program Management efficiencies resulting from better utilization of existing staff; a favorable habitat mitigation fixed price contract; and an underrun due to a favorable bid on the electrical system design for Project W-519.

Impact: There are no impacts.

Corrective Action: $\mathrm{CHG}$ has requested DOE-ORP to reprogram approximately $\$ 4 \mathrm{M}$ of capital line item funding from Project W-519 to expense for other higher priority work.

\subsubsection{9/TW09 Immobilized Tank Waste}

Description and Cause: The favorable cost variance $(\$ 1.1 \mathrm{M} ; 14.5 \%)$ is due to a credit passback for approved reductions in the Fluor Hanford and CHG overhead pools; efficiencies in program management, and ILAW and IHLW engineering studies (sample transport and melter strategy) resulting from better utilization of existing staff (by using similar studies, and having staff more familiar with the work); and a reduction in personnel within the ILAW program. In addition, geotechnical data packages and wind/stack/thermal analysis activities are costing less than anticipated at this time. The first phase of these activities is to gather the information, which costs less than the second phase, which is to prepare the documents.

Impact: There are no impacts.

Corrective Action: Efficiencies have been identified for reallocation to support other CHG needs.

\subsubsection{0/TW10 Management Support}

Description and Cause: The unfavorable cost variance $(-\$ 1.3 \mathrm{M} ;-3.6 \%)$ results from unplanned costs for directed critical path activities, and costs for the BNFL transition. The negative cost variance is partially offset by a credit passback for approved reductions in the Fluor Hanford and CHG overhead pools; and efficiencies gained through better utilization of resources in Construction Project Management, Systems Engineering and Technical Baseline, and Project Integration Office activities. Impacts: There are no impacts.

Corrective Action: Costs for the above activities will be managed through funds control. 


\section{MILESTONE ACHIEVEMENT}

\begin{tabular}{|c|c|c|c|c|c|c|c|c|}
\hline \multirow[t]{2}{*}{ Type } & \multicolumn{4}{|c|}{ Fiscal Year To Date } & \multicolumn{3}{|c|}{ Remaining } & \multirow{2}{*}{$\begin{array}{c}\text { Total } \\
\text { FY 2000 }\end{array}$} \\
\hline & $\begin{array}{l}\text { Completed } \\
\text { Early }\end{array}$ & $\begin{array}{l}\text { Completed } \\
\text { on Schedule }\end{array}$ & $\begin{array}{l}\text { Completed } \\
\text { Late }\end{array}$ & Overdue & $\begin{array}{c}\text { Forecast } \\
\text { Early }\end{array}$ & $\begin{array}{c}\text { Forecast on } \\
\text { Schedule }\end{array}$ & $\begin{array}{l}\text { Forecast } \\
\text { Late }\end{array}$ & \\
\hline $\begin{array}{l}\text { TPA- } \\
\text { Major }\end{array}$ & 0 & 0 & 0 & 0 & 0 & 1 & 0 & 1 \\
\hline $\begin{array}{l}\text { TPA- } \\
\text { Interim }\end{array}$ & 5 & 1 & 1 & 0 & 0 & 5 & 0 & 12 \\
\hline $\begin{array}{c}\text { Consent } \\
\text { Decree }\end{array}$ & 1 & 0 & 0 & 0 & 0 & 1 & 0 & 2 \\
\hline $\begin{array}{l}\text { DOE- } \\
\text { ORP }\end{array}$ & 14 & 6 & 0 & 3 & 0 & 30 & 2 & 55 \\
\hline Total & 20 & 7 & 1 & 3 & 0 & 37 & 2 & 70 \\
\hline
\end{tabular}

Note: This milestone count is based on the approved FY 2000 Bridge Change Request RPP-00-003, and any subsequent approved BCRs. Tri-Party Agreement Major and Interim, and Consent Decree milestones reflect the enforceable agreement dates.

\section{The following milestones have been completed:}

T01-00-103, "M-44-13D, Submit draft TSB-WIRD for FY 2001," due June 30, 2000; completed May 30, 2000.

T01-00-107, "Complete 12 core samples," due September 29, 2000; completed March 10, 2000.

T01-00-112, "Contractor Deliverable for M-44-13D," due May 31, 2000; completed May 18, 2000.

T03-00-056, "M-43-13, Start Construction for Upgrades in the $2^{\text {nd }}$ Tank Farm," due June 30, 2000; completed October 27, 1999.

T03-00-104, "M-46-01F, Concurrence of Additional Tank Acquisition," due November 30, 1999; completed December 1, 1999, based on an approval letter from the Washington State Department of Ecology.

T03-00-203, "Project Plan for Stabilizłng 244-AR," due April 28, 2000; completed April 28, 2000. T03-00-204, "Provide Project Plan for 244-CR," due April 28, 2000; completed April 28, 2000. T03-00-210, "M-45-11A, Submit 244-AR Plan," due April 30, 2000; completed April 28, 2000. T03-00-711, "Start Interim Stabilization of 4 SSTs: 241-U-102, 241-U-103, 24I-U-105, 241-U-109," (Consent Decree D-001-04) due March 31, 2000; completed March 13, 2000. 


\section{Completed Milestones (continued)}

T03-00-750, "Start Interim Stabilization of 4 SSTs: 241-U-102, 241-U-103, 241-U-105, 241-U-109," (contractor deliverable to Consent Decree D-001-04) due March 31, 2000; completed March 13, 2000.

T03-00-753, "FY 2000 Quarter 1 - Maintain Average Pump Efficiency of 40 percent," due December 31, 1999; completed December 31, 1999.

T03-00-754, "Maintain Average Pump Efficiency of 45\%," due March 31, 2000; completed March 31, 2000.

T03-00-757, "Complete Interim Stabilization of 4 SSTs," due September 30, 2000; completed May 11, 2000.

T04-00-102, "AZ-101 Mixer Pump Test," due September 29, 2000; completed June 5, 2000.

T04-00-106, Phase 1 Part B-2 Readiness to Proceed," due April 24, 2000; completed April 24, 2000.

T04-00-441, "M-45-03B, Complete Sluicing Retrieval of Tank 241-C-106 Sludge," due December 31, 1999; completed December 21, 1999.

T04-00-W03, "Transmit Draft B-BX-BY Site Specific Work Plan," due May 22, 2000; completed May 19, 2000.

T04-00-W18, "Demonstrate Start Borehole," due August 31, 2000; completed April 21, 2000.

T04-00-W19, "M-45-52, Submit a Site Specific SST WMA Phase 1 RFI/CMS Work Plan Addenda for WMA S-SX," due October 31, 1999; completed October 29, 1999.

T04-00-W20, "M-45-53, Submit a Site Specific SST WMA Phase 1 RFI/CMS Work Plan Addenda for WMA B-BX-BY," due May 31, 2000; completed May 31, 2000.

T04-00-W25, "Summarize Results of Engineering Studies and Recommendations on Isolating Water Lines in or Near SST WMAs, Sealing Abandoned Wells in or Near SST WMAs, and Controlling Surface Drainage at SST WMAs and Submit to Ecology (M-45-56-T01)," due October 31, 1999; completed October 28, 1999.

T04-00-W95, "Shallow Contamination Characterization," due September 30, 2000; completed February $8,2000$.

T08-00-100, "Sitc Preparation Complete and Ready for BNFL Construction," due March 31, 2000; completed March 31, 2000.

T08-00-110, "Water Utility System Complete (8.1.1)," due May 1, 2000; completed May 1, 2000. T09-00-005, "Issue Waste Form Data Packages for 2001 PA," due December 31, 1999; completed December 29, 1999. 


\section{Completed Milestones (continued)}

T09-00-006, "Complete Advanced Conceptual Studies for Project W-464," due September 1, 2000; completed June 30, 2000.

T09-00-007, "Issue White Paper on ILAW Performance in the Disposal System," due April 28, 2000; completed April 28, 2000.

T09-00-008, "Submit Proposed Strategies and Plans for Disposal of LAW Melters and ILAW Sample Transport and Disposition," due September 29, 2000; completed June 30, 2000.

\section{Milestone Exceptions}

OVERDUE - 3

\begin{tabular}{|c|c|c|c|c|}
\hline$\underline{\text { MS No. }}$ & Level & Milestone Title & $\begin{array}{l}\text { Baseline } \\
\text { Date }\end{array}$ & $\begin{array}{l}\text { Forecast } \\
\text { Date }\end{array}$ \\
\hline $\begin{array}{l}\text { T03-00-057 } \\
1.03 .03\end{array}$ & ORP & $\begin{array}{l}\text { Contractor delive } \\
\text { Start construction }\end{array}$ & $\begin{array}{c}6 / 20 / 00 \\
\text { third tank }\end{array}$ & $10 / 03 / 00$ \\
\hline
\end{tabular}

Cause: Project W-314 AY construction activities are behind schedule due to re-routing the SN transfer line resulting from higher radiation levels than expected in AY farm, and procurement issues associated with $\mathrm{SN}$ transfer line piping.

Impact: Tank farm upgrades have been delayed.

Corrective Action: Excavation of the re-routed SN-635 line is complete. An alternate SN-635 pipe vendor has been selected; and installation of the 635 pipeline is underway to recover the schedule.
T03-00-755 ORP
FY 2000 Quarter 3 - Maintain
$6 / 30 / 00$
N/A

1.01 .03

average pump efficiency of $50 \%$

Cause: Pumping efficiency was not met due to equipment failures.

Impact: There are no impacts at this time.

Corrective Action: Work continues to meet the fourth quarter pumping efficiency milestone T03-00-756, due September 30, 2000.

T04-00-107 ORP Perform a Gap Analysis (ORP 4.5.1) 6/15/00 To be deleted 1.01 .04

Cause: DOE-ORP canceled this work based on the BNFL contract termination.

Impact: There are no impacts.

Corrective Action: A BCR will be prepared to delete this milestone.

FORECAST LATE - 2

T10-00-200 ORP

1.01 .10
Complete Work Management Pilot 8/07/00 at RPP
To be deleted

Cause: This milestone and milestone T10-00-201 (below) are being deleted due to re-focusing on commercial off-thc-shelf software for the business system solution.

Impact: There are no impacts.

Corrective Action: BCR RPP-00-115 is in process to delete the milestones.
T10-00-201 ORP

1.01 .10
RPP Information Systems

Development (10.1.2)
To be deleted 


\section{Section III}

\section{Waste Treatment Plant}

\section{CH2M HILL Hanford Group, Inc. (CHG)}

PROJECT MANAGER:

M. P. Delozier President and General Manager CH2M HILL Hanford Group, Inc. Phone: (509) 372-8061 


\section{Waste Treatment Plant - CH2M HILL Hanford Group, Inc. (CHG)}

The Waste Treatment Plant Design and Operation organizations have been developed and staffed, including transitioning BNFL Inc./Bechtel National Inc. employees to CHG. Since the termination of the BNFL contract, CHG has temporarily assumed the work scope for design and operation of the Waste Treatment Plant. A new waste treatment facility will be built at the Hanford Site in which highly radioactive waste from the tanks will be turned into glass and permanently stored.

A Baseline Change Request is being developed which will update the CHG baseline for operations of the WTP scope for balance of FY 2000 workscope. Once the BCR is approved, costs and schedule will be reported against this work.

\section{SCHEDULE PERFORMANCE}

\begin{tabular}{|l|c|c|c|}
\hline & BCWP & BCWS & VARIANCE \\
\hline WTP TOTAL & $\$ 0$ & $\$ 0$ & $\$ 0$ \\
\hline
\end{tabular}

\section{SCHEDULE VARIANCE}

A Baseline Change Request (BCR) is being developed which will update the CHG baseline for operations of the WTP scope for the balance of FY 2000. Once the BCR is approved, costs and schedule will be reported against this work.

COST PERFORMANCE

\begin{tabular}{|l|c|c|c|}
\hline & BCWP & ACWP & VARIANCE \\
\hline WTP TOTAL & $\$ 0$ & $\$ 0$ & $\$ 0$ \\
\hline
\end{tabular}

\section{COST VARIANCE}

A Baseline Change Request is being developed which will update the CHG baseline for operations of the WTP scope for balance of FY 2000 workscope. Once the BCR is approved, costs and schedule will be reported against this work. 